\title{
1. At the crossroads: The 1951 Geneva Convention today
}

\author{
Julian M. Lehmann
}

\section{INTRODUCTION: EVALUATING THE REFUGEE CONVENTION AT 65}

At the time of writing, the 1951 Geneva Refugee Convention is 65 years old, the traditional age for retirement in many industrialized countries. This chapter will assess the Convention's workforce from the point of view of legal research debates and as applied by states rather than operational policies of the UN High Commissioner for Refugees. It is guided by the questions of whether the Convention is relevant (has the Convention evolved to ensure its continuous application?), effective (do the Convention's provisions serve their purpose, and if not, why?) and whether it is sustainable (are there trends that could challenge the Convention's relevance and effectiveness?). It addresses these questions by outlining contentious issues in respect to the following selection of transversal topics of refugee law research: the development of the Convention's refugee definition; the relation of refugee law to human rights law; the dissonance between the Convention's provisions on criteria for refugee status and substantive rights on the one hand, and access to asylum on the other hand; the universality of the Convention; and, last but not least, the relation of the Convention to politics. The chapter concludes with an assessment on the Convention's future, as well as on research agendas for refugee law. It argues that the evolutionary interpretation of the Convention has limits inherent in the text, some of the most important challenges which refugee law is facing will not be solved 'within' the Convention.

\section{2. ‘...SHALL APPLY TO ANY PERSON WHO...': STRETCHING THE CONVENTION'S REFUGEE DEFINITION}

The 1951 Convention features a catalogue of rights and obligations (Arts 2-34), including the prominent norm of non-refoulement, granted only to those individuals who fall under the refugee definition in Article 1A(2). Given the importance of the refugee definition for the Convention's entitlements, the definition is one of the most salient issues in the judicial and academic debate on the Convention's evolution. While several criteria of the refugee definition have progressed considerably, the limits to its evolution have also become apparent: the Convention retains a distinctive focus and cannot become a catch-all for all forms of displacement.

On the most fundamental level, the relevance of the refugee definition is challenged by the question: why should refugees be privileged over other groups in need, or, why they are 
defined in the way they are defined $?^{1}$ This concerns the Convention requirements of alienage ('is outside the country of nationality') as well as the 'well-founded fear of being persecuted' for a Convention ground (race, religion, nationality, political opinion or membership of a particular social group). Indeed, from its very beginnings, the refugee regime has responded to the disadvantages only of people that were outside, and lost the protection of their country of nationality. This was not just a consideration of need, but also one of legal anomaly and of practicality. The criterion of alienage made sure that states as well as the then responsible agencies could practically act on behalf of refugees, because they would not be compelled to exercise power on foreign territory. ${ }^{2}$ More philosophically, the benefits of refugee status accord refugees a new national home as they are in a disenfranchised, stateless-like situation. ${ }^{3}$ This impetus, it has been argued, flows from the persecutory harm to which a refugee is exposed; refugee status makes her 'as-simil-able': it reduces her otherness given the ostracism faced in her original community. ${ }^{4}$

On a more technical, legal level, the relevance of the Convention has been tested by its evolution to accommodate different forms of harm and discrimination. At the time of adoption, the 1951 Convention's refugee definition was the first to circumscribe both harm and reasons for harm that refugees would face in their respective countries of nationality. Because previous instruments had been limited to particular nationalities, it had until then been unnecessary to elaborate on these points. ${ }^{5}$ As an upshot of that novelty, some of the Convention's key notions, in particular 'being persecuted' and 'membership of a particular social group', were left undefined, ${ }^{6}$ and have proven to be drivers for its evolution.

In that evolution, an important milestone has been the emerging consensus that harm inflicted by non-state actors is relevant for the 'being persecuted' notion, not only when the state authorities are unwilling to provide effective protection, but also when they are unable

1 Satvinder Singh Juss, 'International Migration and Global Justice, Law and Migration Series' (Ashgate Publishing 2006) 198.

2 James C. Hathaway and Michelle Foster, The Law of Refugee Status (2 edn, Cambridge University Press 2014), stating that:

The restriction of refugee status to persons who have left their own country is logical because it defines a class of persons to whom foreign states can, as a matter of practicality, undertake to provide an unconditional response of precisely the kind set by the Refugee Convention.

referring to the principle that States shall not exercise power in the territory of other states, Lotus [1927] Permanent Court of Justice Reports, Series A, No 10, paras 18-19.

3 Communication from the General Council of the International Refugee Organization, Document E/1392, para 5, July 11, 1949:

Lacking the protection of the Government of his country of origin, the refugee does not enjoy a clearly defined status based upon the principle of reciprocity as enjoyed by nationals of those states which maintain normal diplomatic relations. The rights which are conferred on such nationals by virtue of their status, which is dependent upon their nationality, are generally unavailable to him. A refugee is an anomaly in international law [...]

4 For a discussion of various asylum paradigms, see Jean-François Durieux, 'Three Asylum Paradigms' (2013) 20(2) International Journal on Minority and Group Rights 147-77.

5 Atle Grahl-Madsen, 'Protection of Refugees by Their Country of Origin' (1985) 11 Yale Journal of International Law 362.

6 Atle Grahl-Madsen, The Status of Refugees in International Law: Refugee Character (A.W. Sijthoff 1966). McAdam argues that the term, if not explicit in the early instruments of refugee protection, had been implicit in those instruments; see Jane McAdam, 'Rethinking the Origins of 'Persecution' in Refugee Law' (2014) 25 International Journal of Refugee Law 25. 
to do so. ${ }^{7}$ Despite reaching a consensus, there remains some debate when it can be said there is effective protection against harm inflicted by private parties, such as domestic violence claims. $^{8}$

While there is more consensus on most forms of physical harm in more traditional cases of political dissent, there also remains discussion on particular, group-specific forms of harm. The debate on the scope of the 'being persecuted' notion has most recently focused on Lesbian, Gay, Bi- and Intersexual (LGBTI) claimants, after there was significant development on gender-specific harm such as forced marriage, sterilization, forced abortion or forced prostitution. ${ }^{9}$ In LGBTI claims, a controversial issue in academic debate concerned the forms of harm that are relevant to the 'being persecuted' notion, and whether a behaviour modification of an LGBTI claimant in the country of nationality, aimed at evading harm, can itself be persecutory harm. An alternative view is that behaviour modification is simply unreliable, and therefore irrelevant in assessing the risk of harm. ${ }^{10}$

A cross-cutting issue in all controversies on the scope of the 'being persecuted' notion has been the extent to which it should be informed by human rights law. Among the different attempts to further specify the 'being persecuted' notion, ${ }^{11}$ the most influential one relies on human rights as guidance to define the scope of relevant harm. This approach is not only used by the UNHCR in its authoritative Handbook on Procedures and Criteria Determining Refugee Status, ${ }^{12}$ but also by numerous courts in both civil and common law jurisdictions. ${ }^{13}$

Meanwhile, this 'human rights approach', as it is often called, is not without contention. Critics of the approach caution that the distinctive content of the 'being persecuted' notion could get lost. ${ }^{14}$ Even among proponents of the human rights approach, there has been debate about single aspects. In particular, this includes the theoretic rationale on how to identify which human rights are relevant and which are not, and, in consequence, the scope of relevant harm. Some have argued that the being persecuted notion should essentially compare to the scope of the prohibition of inhuman or degrading treatment as contained internationally in

7 For a summary of the debate, see Walter Kälin, 'Non-state Agents of Persecution and the Inability of the State to Protect' (2000) 15 Georgetown Imigration Law Journal 415.

8 Michael G. Heyman, 'Domestic Violence and Asylum: Toward a Working Model of Affirmative State Obligations’ (2005) 17(4) International Journal of Refugee Law 729-48.

9 Deborah Anker, 'Refugee Law, Gender, and the Human Rights Paradigm' (2002) Harvard Human Rights Journal 133.

10 James C. Hathaway and Jason Pobjoy, 'Queer Cases Make Bad Law' (2012) 44(2) Journal of International Law and Politics 315-89.

11 For an analysis of different ways, see Hathaway and Foster (n 2).

12 UN High Commissioner for Refugees, Handbook on Procedures and Criteria for Determining Refugee Status under the 1951 Convention and the 1967 Protocol Relating to the Status of Refugees para 51. For a position similar to the UNHCR Handbook's, see the 1995 Commentary by Weis - Weis, The Refugees Convention, 1951: The Travaux Préparatoires Analysed with a Commentary by Dr Paul Weis - according to which:

At the very least, a connection exists between' persecution and the failure on the part of states to observe certain human rights. The reference contained in the Preamble to the Convention concerning the principle that human beings shall enjoy fundamental rights and freedoms may provide a context for advancing the view that the violation of certain rights may either constitute persecution per se, or evidence thereof.

13 For a list of cases, see Hathaway and Foster (n 2), 185, 196.

14 E.g., David James Cantor (ed.), Human Rights and the Refugee Definition - Comparative Legal Practice and Theory (International Refugee Law Series, Brill 2016). 
the UN Convention against Torture and Other Cruel, Inhuman or Degrading Treatment or Punishment (UNCAT), the International Covenant on Civil and Political Rights (ICCPR), and regionally in the European, Intra-American and African Conventions on human rights. ${ }^{15}$ Others have proposed tying the notion to a hierarchy of duty under international human rights law, in which all harm that falls in the ambit of a human rights norm and is not covered by a limitation clause is relevant, including harm that would not pass the threshold of inhuman or degrading treatment. ${ }^{16}$ Ultimately, both approaches face distinct challenges. While the latter approach needs to define limits to its inclusiveness, the former approach could risk ignoring the growing practice on other claims, including on violations of social and economic rights. ${ }^{17}$

The debate over the scope of harm relevant to the being persecuted notion is closely tied to the refugee definition's nexus requirement, which determines eligibility based on persecution related to race, religion, nationality, political opinion, or membership of a particular social group. That criterion has, on the one hand, witnessed a gradual evolution through the relatively flexible concept of a particular social group. To a greater extent than the other categories, the particular social group concept has been interpreted in a way that accommodates types of claims not anticipated at the time of drafting. In addition to sex and gender as defining elements for a particular social group, the concept has extended to claims in which the particular social group is the family or clan, a particular age-group, or people with disabilities. ${ }^{18}$ On the other hand, the nexus criterion also demonstrates some of the limits to the Convention's continued evolution. First, although there is a wide array of circumstances in which the 1951 Convention can accommodate the claims of individuals fleeing armed conflict, ${ }^{19}$ the nexus clause remains an insurmountable hurdle when it comes to the recognition of refugee status for people fleeing indiscriminate violence, rather than violence that targets specific groups or disproportionately affects specific groups. Second, courts have so far been reluctant to consider economic status a defining element, thus the Convention is unlikely to cover individuals fleeing economic destitution. ${ }^{20}$ Likewise, it is questionable whether courts will recognize any particular social group in the face of indiscriminate consequences of natural disasters, including those induced by climate change. ${ }^{21}$ Finally, it is clear that the particular social group concept cannot evolve

15 Hugo Storey, 'What Constitutes Persecution? Towards a Working Defintion' (2014) 26 International Journal of Refugee Law 272.

16 Hathaway and Foster (n 2).

17 For ESCR, see Michelle Foster, International Refugee Law and Socio-economic Rights: Refuge From Deprivation (Cambridge University Press 2007), Vol. 51.

18 Michelle Foster, The 'Ground with the Least Clarity': A Comparative Study of Jurisprudential Developments relating to 'Membership of a Particular Social Group' (UNHCR Legal and Protection Policy Research Series, 2012).

19 Vanessa Holzer, The 1951 Refugee Convention and the Protection of People Fleeing Armed Conflict and Other Situations of Violence. UNHCR, 2012.

${ }_{20}$ For the limited circumstances of cases fitting into the refugee definition, see Foster (n 17); Kate Jastram, 'Economic Harm as a Basis for Refugee Status and the Application of Human Rights Law to the Interpretation of Economic Persecution' in James Simeon (ed.) Critical Issues in International Refugee Law: Strategies Toward Interpretive Harmony (Cambridge University Press 2010); James C. Hathaway, 'Food Deprivation: A Basis for Refugee Status? (2014) 81(2) Social Research: An International Quarterly 327-39. For other types of claims, see also Alexander Betts, 'Towards a 'Soft Law' Framework for the Protection of Vulnerable Irregular Migrants', (2010) 22 (2) International Journal of Refugee Law 209-36.

${ }^{21}$ For potential discriminatory circumstances in such cases, see Matthew Scott, 'Refugee from Climate Change-Related Harm: Evaluating the Scope of International Protection within the Common 
to the degree that the defining element would be simply the fear of being persecuted, or victimhood, for the criterion would otherwise be superfluous.

\section{ONE-SIDED DEPENDENCE? HUMAN RIGHTS LAW AND THE FUTURE OF THE 1951 CONVENTION}

Because there are boundaries to the evolutionary interpretation of the Convention, other bodies of law have increasingly gained relevance for the Convention. Human rights law has become not only the primary tool to interpret the relevant harm for the 'being persecuted' notion and (to a far lesser degree) interpret the scope of the Convention grounds. Not least important, human rights law is also complementing the gaps of the Convention in respect of both its refugee definition and the substantive rights under Articles 2-34 of the Convention.

Regarding the definition, it is now long-standing practice that certain norms of human rights law entail obligations of non-return. The rationale of such "non refoulement law'22 is that the sending state incurs liability for exposing an individual to a real risk of serious and irreparable harm. In contrast to the 'being persecuted notion' in the 1951 Refugee Convention, such harm must not necessarily be linked to a discriminatory ground, so that human rights law non-refoulement obligations may in some cases be wider in scope.

Jurisprudence on non-refoulement law was pioneered by the European Court of Human Rights, in the Soering case, ${ }^{23}$ but that jurisprudence also influenced the interpretation of obligations under other human rights law treaties, in particular under the ICCPR. ${ }^{24}$ What is more, there are similar obligations under the Convention against Torture, ${ }^{25}$ and the Convention on the

European Asylum System' in Céline Bauloz et al. (eds), Seeking Asylum in the European Union (Brill 2015).

${ }^{22}$ Jean-François Durieux, 'The Vanishing Refugee: How EU Asylum Law Blurs the Specificity of Refugee Protection' in Hélène Lambert, Jane McAdam and Maryellen Fullerton (eds), The Global Reach of European Refugee Law (The Global Reach of European Refugee Law, Cambridge University Press 2013).

${ }_{23}$ Soering v. the United Kingdom App No 14038/88 [1989] 11 EHRR 439, in particular para 91:

The establishment of such responsibility inevitably involves an assessment of conditions in the requesting country against the standards of Article 3 (art. 3) of the Convention. Nonetheless, there is no question of adjudicating on or establishing the responsibility of the receiving country, whether under general international law, under the Convention or otherwise. In so far as any liability under the Convention is or may be incurred, it is liability incurred by the extraditing Contracting State by reason of its having taken action which has as a direct consequence the exposure of an individual to proscribed ill-treatment.

24 Hélène Lambert, 'Consolidation and Development of the Asylum-Related Jurisprudence of the European Court of Human Rights - Key-Note Speech to the Second Colloquy on the European Convention on Human Rights and the Protection of Refugees, Asylum-Seekers and Displaced Persons' (2000) SSRN eLibrary. On the obligations, see Human Rights Committee, General Comment No. 31 [80] The Nature of the General Legal Obligation Imposed on State Parties to the Covenant, CCPR/ Rev.1/Add. 13, 26 May 2004 para 12. See also Human Rights Committee, General Comment 20, Art 7 (44th session, 1992), Compilation of General Comments and General Recommendations Adopted by Human Rights Treaty Bodies, UN Doc. HRI/GEN/1/Rev.1 at 30 (1994) para 9.

25 Convention against Torture, art 3(1): 'No State Party shall expel, return ('refouler') or extradite a person to another State where there are substantial grounds for believing that he would be in danger of being subjected to torture.' 
Rights of the Child. ${ }^{26}$ In principle, multiple human rights norms could entail non-refoulement obligations. ${ }^{27}$ In practice, however, these obligations have almost exclusively remained limited to the prohibition of torture, inhuman or degrading treatment or punishment, ${ }^{28}$ which was found relevant in a plethora of different cases that range from indiscriminate violence to lacking medical treatment or dire humanitarian conditions in situations of armed conflict. ${ }^{29}$ Meanwhile, whether or not human rights non-refoulement law is broader than the Refugee Convention chiefly depends on interpretation. Ironically, only if the Convention's being persecuted notion is interpreted inclusively, covering other human rights harm than inhuman or degrading treatment, will the refugee definition retain its distinct characteristics vis-à-vis the scope of harm relevant for human rights non-refoulement law.

For the future of the Convention, the complementary role of human rights law for the Convention's substantive entitlements is potentially even more important than the complementarity of human rights non-refoulement law. In contrast to human rights law, which unconditionally applies to everyone within the territory and subject to the jurisdiction of a state party (that is, also extraterritorially, and irrespective of legal status), ${ }^{30}$ the 1951 Convention's catalogue of rights and obligations is contingent on the level of attachment with the asylum state. Although there are some obligations owed to refugees who are merely under a state party's jurisdiction, ${ }^{31}$ or are physically present, a significant number of obligations require either lawful presence, lawful stay or durable residence by the refugee. ${ }^{32}$ Moreover, the

26 UN Committee on the Rights of the Child, CRC General Comment No. 6 (2005): Treatment of Unaccompanied and Separated Children Outside their Country of Origin, 1 September 2005, CRC/ GC/2005/6 (2005) para 27:

in fulfilling obligations under the Convention, States shall not return a child to a country where there are substantial grounds for believing that there is a real risk of irreparable harm to the child, such as, but by no means limited to, those contemplated under articles 6 and 37 of the Convention, either in the country to which removal is to be effected or in any country to which the child may subsequently be removed.

27 In F. v United Kingdom, the court stated that while 'on a purely pragmatic basis, it cannot be required that an expelling contracting state only return an alien to a country which is in full and effective enforcement of all the rights and freedoms set out in the Convention', there may be an issue arising under art 6 ECHR in case of a flagrant denial of the right to a fair trial. This was first applied in Othman (Abu Qatada) v. United Kingdom App No 8139/09, ECHR 2012.

28 E.g., Communication No. 1544/2007, Mehrez Ben Abde Hamida v. Canada, 18 March 2010; communication No. 692/1996, A.R.J. v. Australia, 28 July 1997; X. v. Sweden, 1 November 2011. For the scope of non-refoulement obligations under the ICCPR, see e.g., Cornelis Wolfram Wouters, International Legal Standards for the Protection from Refoulement (Intersentia 2009).

29 Jane McAdam, Complementary Protection in International Refugee Law (Oxford University Press 2007); David James Cantor and Jean-Francois Durieux (eds), Refuge from Inhumanity? War Refugees and International Humanitarian Law (International Refugee Law, Brill 2014).

30 As a general rule, the ICCPR applies without discrimination between nationals and non-nationals. See Human Rights Committee, General Comment No. 31 [80] The Nature of the General Legal Obligation Imposed on State Parties to the Covenant, CCPR/Rev.1/Add. 13, 26 May 2004 para 10; see also Human Rights Committee, CCPR General Comment No. 15: The Position of Aliens Under the Covenant, UN Doc. HRI/GEN/1/Rev.1, 18.

31 For a discussion of jurisdiction in the more contested contexts of refugee law, see Thomas Gammeltoft-Hansen, Access to Asylum - International Refugee Law and the Globalisation of Migration Control (Cambridge University Press 2011).

32 James C. Hathaway, The Rights of Refugees under International Law (Cambridge University Press 2005). The meaning of these concepts is, according to Hathaway, 'defined by practical circumstances 
Convention seeks treatment that is as favourable as possible, yet its minimum obligation is only non-discrimination with other 'aliens generally in the same circumstances' ${ }^{33}$ or 'the most favourable treatment accorded to nationals of a foreign country, in the same circumstances'. ${ }^{34}$ This particular structure of entitlement has led to debate about its relevance in comparison to human rights law. Thus, it has been argued that the Convention increasingly loses relevance..$^{35}$

Indeed, most of the substantive Convention rights of refugees are also guaranteed by human rights law, albeit only if that body of law is interpreted in an evolutionary and inclusive way, in particular on the scope of obligations under economic, social and cultural rights. However, the Convention prescribes that refugees shall be treated as favourably as their own nationals in areas that can be particularly sensitive and contested under human rights law, including freedom of religion, access to a rationing system, public relief and social security, employment, and elementary education. What is more, its duty to facilitate the naturalization of refugees finds no expression in human rights law. Ultimately, whether the Convention will retain its relevance will depend on authorities, lawyers and courts relying on its distinct provisions rather than on omnipresent human rights law. An example of such reliance is the recent EU Court of Justice case M'Bodj v. Belgium, in which the court extended the higher standards of protection of the 1951 Convention in respect to free movement of individuals enjoying complementary forms of protection ('subsidiary protection' in EU jargon). ${ }^{36}$

\section{NO ACCESS, NO STATUS; NO SOLIDARITY, NO PROTECTION: WHERE THE CONVENTION IS SILENT}

A bigger problem for the effectiveness of the Convention than its multi-level entitlements may be its application to policies aimed at deterring refugees or returning refugees to places of substandard protection, and its silence on responsibility and burden sharing, issues often referred to as 'access to protection'.

Driven by the desire to control inflows, states resort to practices of migration control that take physical as well as legal forms and are no longer confined to their own territories, but take effect in the territories of other states too. The legality of such measures is under the current refugee protection system primarily a matter of the applicability and scope of non-refoulement, in Article 33 of the Convention. From a refugee legal research perspective, the least 'problematic' of such measures are the more traditional scenarios that can be covered by an evolving understanding of jurisdiction no longer fixated on spatial criteria alone. Thus, there is a growing body of practice supporting the view that jurisdiction can be triggered by control over persons, so that the Convention not only applies to transit facilities, but also extraterritorially, in par-

rather than by any official decision or status', because of the declaratory nature of recognition of refugee status, ibid., 198.

33 E.g. art 18

34 E.g. art 15.

35 Vincent Chetail, 'Are Refugee Rights Human Rights? An Unorthodox Questioning of the Relations between Refugee Law and Human Rights Law' in R. Rubio Marin (ed.), Migration and Human Rights (Migration and Human Rights, Oxford University Press 2011).

36 Mohamed M'Bodj v. Belgian State Judgment of the Court of 18 December 2014 (unreported) (CJEU). 
ticular on the high seas. ${ }^{37}$ However, academic literature also recognized a trend of various, more subtle forms of migration control: these include carrier sanctions, incentives and support for border operations in other states, such as through immigration liaison officers, support for pull-back operations by foreign authorities, or the privatization of migration control. ${ }^{38}$ Making the Convention's non-refoulement obligation relevant for such measures is fraught with legal difficulty - in particular, on the scope of a personal model of jurisdiction, on the attribution of conduct to a state by a private person or group of persons, and state responsibility for aiding or assisting another state with the commission of a wrongful act. For instance, it is highly unlikely that the current measures of cooperation in the Mediterranean, targeted financial assistance, or the provision of technical equipment by EU states to strengthen capacity for border protection, ${ }^{39}$ could trigger joint responsibility for a wrongful act committed by one of the supported states. Indeed, these measures are laying bare how easily international responsibility can be circumvented under the current system. Yet, as Hathaway and Gammeltoft-Hansen observe, states may in the future face a trade-off between effective deterrence and lawfulness, which may ultimately push them to adopt measures that trigger legal liability.

The inclination to become more directly involved in order to achieve more control and thereby to increase the likelihood of efficacy thus often pushes states to the more interventionist end of the spectrum of contemporary non-entrée. Yet it is when a state's own personnel are deployed in aid of deterrence abroad or where joint or shared enforcement is established that legal liability becomes most clear. ${ }^{40}$

While the Convention has evolved on key refugee law concepts and thus assured its continued relevance to migration control, it has remained stagnant on another key issue: solidarity, which is key to a global displacement situation that affects some countries and regions far more than others. ${ }^{41}$ Although the drafters were aware of that imbalance, the Convention neither regulates the 'sharing' of people (responsibility sharing), nor the sharing of financial resources (burden sharing). ${ }^{42}$ Crucially, the Convention does not compel states to proactively admit refugees from foreign territories. In the international refugee regime established by the Convention, the distribution of refugees to particular countries therefore continues to depend primarily on the agency of refugees themselves, who, within the realms of their legal, physical and financial possibilities, pick one country, as well as on the norm of non-refoulement, which prohibits

37 Guy S. Goodwin-Gill, 'The Right to Seek Asylum: Interception at Sea and the Principle of Non-refoulement' (2011) International Journal of Refugee Law 23; Cathryn Costello, 'Courting Access to Asylum in Europe: Recent Supranational Jurisprudence Explored' (2012) 12 Human Rights Law Review 287; Gammeltoft-Hansen (n 31).

38 Ibid.; Tilman Rodenhäuser, 'Another Brick in the Wall: Carrier Sanctions and the Privatization of Immigration Control' (2014) 26(2) International Journal of Refugee Law 223-47.

39 For EU cooperation with third countries, see Paula García Andrade et al., EU Cooperation with Third Countries in the Field of Migration, study for the LIBE Committee, 2015, http://www.europarl .europa.eu/RegData/etudes/STUD/2015/536469/IPOL_STU(2015)536469_EN.pdf, last accessed 9 April 2019.

40 James Hathaway and Thomas Gammeltoft-Hansen, 'Non-Refoulement in a World of Cooperative Deterrence' (2014) University of Michigan Law School Law \& Economics Working Papers, Paper 106.

${ }^{41}$ UNHCR Global Trends. The drafters of the Convention did acknowledge that sharing burdens was crucial to an effective international response to forced displacement.

42 For this typology, see Gregor Noll, 'Risky Games? A Theoretical Approach to Burden Sharing in the Asylum Field' (2003) 16 Journal of Refugee Studies 236-52. 
returning refugees back to persecution, including by not admitting them to the territory where the denial of admission would result in their exposure to persecution. ${ }^{43}$ Indeed, the task of remedying the silence of the Convention when it comes to sharing people has fallen largely upon non-refoulement obligations from refugee and human rights law. Thus, the sending of individuals to countries with heavily defunct asylum systems can be contested as indirect (or 'chain') refoulement under the Convention, or be prohibited by the right to freedom from inhuman or degrading treatment, in case it leads to returns that expose an individual to a real risk of relevant harm.

More controversial are the Convention's safeguards with regard to returns to countries with a poor quality of protection, but below the threshold of indirect refoulement or an exposure to inhuman or degrading treatment in the receiving state. The Convention does not compel refugees to seek protection in the first state where there is an opportunity to do so, but neither explicitly prohibits return to a place where refugees are not granted all the rights under the Convention. This void has led to numerous arrangements that can be referred to as 'protection elsewhere', such as 'first country of asylum' and 'safe third country' concepts. ${ }^{44}$ While it has been argued that the Convention precludes stripping refugees of acquired rights (and thus bars return to countries that disregard Convention rights), ${ }^{45}$ the minimum standards for 'protection elsewhere' arrangements remain contested.

Meanwhile, what is more certain is that proactive forms of admission, such as resettlement and humanitarian admission, are currently being left entirely to the realm of politics, because they are not prescribed by law. Developed countries have preferred such types of admission to spontaneous arrivals, a trend that may increase amid security concerns over spontaneously arriving refugees and domestic political opposition to high intakes. ${ }^{46}$ As this preference is unlikely to translate into legal norms, and states engage in cooperative non-entré policies whose lawfulness cannot easily be challenged, legal research is challenged to find its place on the most pressing issues the Convention faces.

\section{THE TEMPORAL LIMITATION THAT WAS: THE CONVENTION AS A UNIVERSAL INSTRUMENT?}

In the genesis of modern refugee law, the 1951 Convention sticks out as the first legal instrument that does not apply to a particular nationality only, after early institutions and treaties had applied to, among others, Russians escaping the October Revolution, Armenians escaping

\footnotetext{
43 On the scope of non-refoulement, see Hathaway (n 32), 300. Less attention was paid to the ramifications and scope of the right to leave any country, including one's own. See Nora Markard, 'The Right to Leave by Sea: Legal Limits on EU Migration Control by Third Countries' (2016) European Journal of International Law 27.

44 Michelle Foster, 'Protection Elsewhere: The Legal Implications of Requiring Refugees to Seek Protection in another State' (2007) Michigan Journal of International Law 223.

45 Ibid. also Hathaway and Foster (n 2).

46 Reports that the self-proclaimed Islamic State or Daesh trains Djihadists to succeed in asylum interviews.
} 
the Ottoman government, or Germans escaping Nazi persecution. ${ }^{47}$ In contrast, the 1951 Convention, even in its early drafts, does not apply to the nationals of particular countries. ${ }^{48}$

Despite its relatively broad refugee definition, the Convention was fundamentally a response to the displacement in Europe. Although the drafters of the Convention had expressed their hope that the application of the Convention would be expanded to other contexts too, ${ }^{49}$ governments had been reluctant to embrace a universal refugee definition..$^{50}$ The Convention thus included a temporal limitation to events before 1951, and was allowed to restrict its application to Europe only. Pragmatic action circumvented this limitation quickly, ${ }^{51}$ but the Convention retained a stigma of a Eurocentric post-World War instrument.

With the adoption of the 1967 Protocol Relating to the Status of Refugees (the Protocol), the Convention finally provided the basis for universal application. However, the debate about the Convention's universality does not stop here. In gauging universality, it is helpful to distinguish between different levels: relative universality at the level of a concept (level one), which in turn is characterized by several different conceptions (level two) and implementations (level three). ${ }^{52}$ Propelled by the observation that some underlying concepts of the 1951 Convention - providing sanctuary or demonstrating hospitality to strangers - date back to the medieval period in Europe and around the world, ${ }^{53}$ the Convention's standard-setting for a particular group of needy foreigners does have universal appeal. There is also a fair degree of international legal universality at level one, given the high number of ratifications ${ }^{54}$ and high-level processes reaffirming the Convention. In the 2001 Declaration of State Parties to the Convention and the Protocol, ${ }^{55}$ and most recently the New York Declaration, ${ }^{56}$ governments have reaffirmed their commitment to implement their obligations under these instruments.

However, such conceptual universality does not mean shared conceptions of all Convention provisions, which frequently allow for different interpretations. Indeed, there are a number

47 Paul Weis, 'The International Protection of Refugees' (1954) American Journal of International Law 193.

48 Ad Hoc Committee on Statelessness and Related Problems, Summary Record of the Seventh Meeting, held at Lake Success, New York, 31 January 1950 (UN Doc. E/AC32/SR17, 1950).

49 Final Act of the United Nations Conference of Plenipotentiaries on the Status of Refugees and Stateless Persons, 25 July 1951, http://www.unhcr.org/protection/travaux/40a8a7394/final-act-united -nations-conference-plenipotentiaries-status-refugees-stateless.html, last accessed 9 April 2019.

50 Kazimierz Bem, "The Coming of a "Blank Cheque" - Europe, the 1951 Convention, and the 1967 Protocol' (2004) 16 International Journal of Refugee Law 609.

51 See the account of the gradual expansion of UNHCR's mandate, Alexander Betts and Gil Loescher, The United Nations High Commissioner for Refugees (UNHCR): The Politics and Practice of Refugee Protection (Global Institutions, Routledge 2013).

52 Jack Donnelly, 'The Relative Universality of Human Rights' (2007) 29(2) Human Rights Quarterly 281-306.

53 Linda Rabben, Sanctuary and Asylum: A Social and Political History (University of Washington Press 2016).

54 For a list of ratifications to the Convention and the Protocol, see United Nations Treaty Series, http://www.unhcr.org/protection/basic/3b73b0d63/states-parties-1951-convention-its-1967-protocol .html, last accessed 9 April 2019.

${ }_{55}$ UN High Commissioner for Refugees (UNHCR), Declaration of States Parties to the 1951 Convention and or Its 1967 Protocol relating to the Status of Refugees, 16 January 2002, HCR/ MMSP/2001/09.

56 UN General Assembly, New York Declaration for Refugees and Migrants, A/71/L.1, 13 September 2016. 
of contentious issues on the interpretation of Convention provisions, some of which have been mentioned in this chapter or are discussed in this volume. They include, among others, the scope of the refugee definition; the threshold for cessation of refugee status; the scope of refugee rights, including access to welfare and extraterritorial application of the duty of non-refoulement; the criteria for exclusion, or even the understanding of basic terms as 'protection'. Yet, different legal conceptions do not mean that there is an indefinite range of permissible interpretations. As it was put in a UK case grappling with divergent interpretations of the Convention, 'however wide the canvas facing the judge's brush, the image he makes has to be firmly based on some conception of objective principle which is recognized as a legitimate source of law' ${ }^{57}$ As law is conveyed through language and as language is indeterminate, a community of practice (legislative, executive and judicial actors) struggles over semantics, upholds and develops law with shared understandings based on common interpretative means and rules. ${ }^{58}$ Those means and rules are primarily the rules of interpretation of the Vienna Convention on the Law of Treaties, which prescribe an approach to the Convention that builds on 'consistency with principle, [...] object and purpose, and good faith' ${ }^{59}$ The Convention's universality cannot be taken for granted, but needs continuous and principled affirmation by a community of practice. From the perspective of refugee law research (this contribution is no exception), that community of practice tends to be composed mainly of courts of industrialized countries that handle individual claims, missing out on practice in the Global South. What is more, refugee law research has only recently begun to study the emulation and cross-pollination of refugee law between different legal systems in a systematic way, ${ }^{60}$ and tends to treat compliance as a direct consequence of positive law. This is where the Convention's supervision and relation to politics comes into play.

\section{THE POLITICS OF PROTECTION: COMPLYING WITH 1951 CONVENTION OBLIGATIONS}

Focusing on countries with relatively sophisticated refugee status determination and functioning domestic legal enforcement creates a limited frame for analysing compliance questions in refugee law research: they are most often addressed as part of doctrinal analysis, aiming at the systematic description and criticism of positive law. The quest for a broad interpretation of the refugee definition in Article 1A(2), and the systematic description of obligations towards specific subsets of refugees, is a case in point. This focus has ensured refugee research remains relevant to the practice of immigration lawyers and the broader debate on the legality of contested measures of immigration control; however, it has somewhat missed out on theoretical and empirical research on compliance mechanisms with the Convention.

57 Sepet v. Secretary of State for the Home Department, [2001] Imm AR 452 (Eng. CA, May 11, 2001), at 477 [66].

58 Jutta Brunnée and Stephen J. Toope, Legitimacy and Legality in International Law (Cambridge University Press 2010), 352; Ingo Ventzke, How Interpretation Makes International Law (Oxford Universtiy Press 2012).

59 Goodwin-Gil cited in James C. Simeon, 'Introduction: The Research Workshop on Critical Issues in International Refugee Law and Strategies Towards Interpretative Harmony' in Simeon (n 20), 9.

60 Lambert, McAdam and Fullerton (n 22). 
Research on international law compliance is interested in why states commit to international legal obligations, why they do or do not comply with legal obligations after having committed to them, and what the mechanisms of enforcement are. The first question is most conventionally answered by pointing to state power and interests. Interests can be affected by incentives of meaningful enforcement, such as linking ratification with rewards, reciprocity or reputational sanctions. ${ }^{61}$ Yet, given the lack of centralized enforcement, these explanations normally struggle to explain commitments to human rights treaties. ${ }^{62}$ Scholars have therefore pointed to the importance of domestic factors for ratifying and complying with human rights treaties, for instance, as a tactical concession to the demands of rights proponents. ${ }^{63}$ These factors cannot, in turn, be easily applied to refugee law, as they posit that it is citizens advocating for their own rights (and potentially supported internationally) that push compliance. Research on compliance with refugee law, and on the readiness to expand it, has pointed in various directions, including the centrality of domestic pressure and relations with the country of origin of asylum seekers,${ }^{64}$ the importance of linking protection to other issues at the core of state interest, ${ }^{65}$ but also the aversion of states to rights-based language and legal protection. Indeed, it has been argued that human rights-based approaches and protection activities have been detrimental to 'on the ground' solutions for refugees in the Middle East. ${ }^{66}$

Perhaps more widely discussed is compliance with the Convention in relation to the supervision of the 1915 Convention and UNHCR initiatives aimed at strengthening the Convention. Article 35 of the 1951 Convention bestows on the UNHCR the competence to supervise the application of the Convention, while imparting on states the duty to cooperate with the High Commissioner. In practice, the UNHCR supervisory role has included a broad scope of activities. These range from representations to governments, submissions to court cases, advice on draft legislation and on refugee status determination, public advocacy, capacity building and data collection. ${ }^{67}$ However, the 'good offices' role of UNHCR supervision remains different from the monitoring of human rights treaties. The UNHCR does issue interpretative guidelines

${ }^{61}$ Beth A. Simmons, 'Compliance with International Agreements' (1998) 1(1) Annual Review of Political Science 75-93.

${ }_{62}$ Richard A. Nielsen and Beth A. Simmons, 'Rewards for Ratification: Payoffs for Participating in the International Human Rights Regime?' (2015) 59(2) International Studies Quarterly 197-208.

${ }_{63}$ Thomas Risse and Kathryn Sikkink, 'The Socialization of International Human Rights Norms into Domestic Practices: Introduction' (1999) 66 Cambridge Studies in International Relations 1-38.

64 Domestic and international incentives of elites, including pressures from civil society and bilateral relation with the country of asylum comparing South Africa and Botswana, Alexander Betts, 'From Persecution to Deprivation: How Refugee Norms Adapt at Implementation' in Alexander Betts and Phil Orchard (eds), Implementation \& World Politics - How Internationa Norms Change Practice (Implementation \& World Politics - How Internationa Norms Change Practice, Oxford University Press 2014).

${ }_{65}$ Alexander Betts, Protection by Persuasion: International Cooperation in the Refugee Regime (Cornell University Press 2009).

${ }_{66}$ Jill Goldenziel, 'Regulating Human Rights: International Organizations, Flexible Standards, and International Refugee Law' (2014) Chicago Journal of International Law 14; Dallal Stevens, 'Rights, Needs or Assistance? The Role of the UNHCR in Refugee Protection in the Middle East' (2016) 20 The International Journal of Human Rights 20.

67 Walter Kälin, 'Supervising the 1951 Convention Relating to the Status of Refugees: Article 35 and Beyond' in Erika Feller, Volker Türk and Frances Nicholson (eds), Refugee Protection in International Law: UNHCR's Global Consultations on International Protection (Refugee Protection in International Law: UNHCR's Global Consultations on International Protection, Cambridge University Press 2003). 
on the interpretation of the 1951 Convention (such as the Handbook on Refugee Status and the Guidelines on International Protection), but the Convention has neither a reporting nor a complaint mechanism. Academics and practitioners have thus made several proposals aimed at strengthening supervision of the Convention. Partly modelled after the mechanisms of human rights treaties, and with different degrees of 'embedding' into the UNHCR. These proposals included regular reporting obligations, a refugee rights committee, or a sub-committee of UNHCR's Executive Committee, tasked with monitoring and featuring thematic rapporteurs. ${ }^{68}$ Most recently, a group of academics and judges proposed the creation of a Special Committee of Experts within the UNHCR, 'tasked with issuing Advisory Opinions on the interpretation and application of the [...] Convention.' ${ }^{69}$

Yet, there has been little appetite on the part of states to make supervisory institutions for the Convention more robust or to add new legal obligations. This has been apparent not only in the lack of reform on supervision, but also in the UNHCR's 'Convention Plus' initiative (aimed at complementing the Convention with multilateral special agreements on the strategic use of resettlement, more targeted development assistance to facilitate solutions for refugees and on state obligations in handling irregular secondary movements ${ }^{70}$ and in the negotiations of the Global Compact for Refugees, equally facilitated by the UNHCR. For future legal research, it will be particularly relevant to observe the normative impact of the Global Compact for Refugees on the 1951 Convention practice and on the global protection regime more broadly by states and the UNHCR, but also by other stakeholders that are traditionally not in focus of legal research. Finally, legal research will have to grapple with how it can contribute to more burden and responsibility sharing. ${ }^{71}$

\section{CONCLUSION: AT THE CROSSROADS}

The 1951 Convention is at a critical juncture, and so is legal research on the Convention. Looking back, the Convention has undergone a remarkable evolution. It has remained relevant by proving flexible, in particular regarding the use of human rights law as interpretative guidance for elements of the refugee definition. The changed understanding of jurisdiction in public international law has expanded the applicability of Convention rights and obligations owed to refugees under the jurisdiction of a state party (rather than a more demanding form of physical presence or legal status), in particular non-refoulement. Finally, the Convention has long overcome the initial post-war, Eurocentric bias.

However, the Convention is also facing challenges that either already hamper its relevance and effectiveness, or could do so in the future. First, the research debates on the evolutionary interpretation of the definition and the stretching of the definition have probably reached their

68 James C. Simeon, 'The Supervision of International Refugee Law' (International Refugee Law Seminars, London, 21 February 2012).

69 James C. Hathaway, Anthony M. North, Jason M. Pobjoy, and Rosemary Byrne. 'Roundtable on the Future of Refugee Convention Supervision' (2013) 26(3) Journal of Refugee Studies 323-6.

70 Marjoleine Zieck, 'Doomed to Fail from the Outset? UNHCR's Convention Plus Initiative Revisited' (2009) 21 International Journal of Refugee Law.

71 On the Convention Plus initiative, this question has been researched by Alexander Betts and Jean-François Durieux, 'Convention plus as a norm-setting exercise' (2007) 20 Journal of Refugee Studies. 
climax; the Convention cannot and should not lose its distinctive focus on actor-inflicted human rights harm connected to a Convention ground. From the vantage point of future refugee law research, material law on the scope of the refugee definition could lose relevance to the benefit of procedural analysis as the new 'battleground' for how a case is decided, in particular given 'protection elsewhere' practices. Second, human rights law is not only a motor to the evolutionary interpretation of the Convention. It also risks cannibalizing the Convention should the scope of harm relevant for human rights law non-refoulement obligations under human rights law be interpreted more broadly than that of the Convention, and if human rights law continues to evolve more dynamically than the Convention. Third, to endure and maintain universal appeal, the Convention needs continuous application by a community of practice committed to objective principle, all the while the Convention is under constant strain of measures for migration control, and despite imperfect supervisory mechanisms. In this regard, other developments in international law, such as on complicity and on joint responsibility in extraterritorial obligations, will continue to be relevant for the 1951 Convention. Finally, some of the most important challenges, such as non-compliance, climate-induced displacement and the lack of solidarity in the refugee regime, are unlikely to be solved 'within' the Convention, but need other regulatory frameworks, possibly not even in the form of 'hard' law. To some extent, this may mean that dogmatic legal research becomes less policy-relevant, to the benefit of research on compliance factors, other disciplinary outlooks and applied research contributing to functioning institutions of refugee protection. For only if the international protection regime evolves alongside the Convention, will the instrument continue to be relevant. 